\title{
W.
ELSEVIER
}

\section{Corpus Callosum Anomalies: Birth Prevalence and Clinical Spectrum in Hungary}

\author{
Nóra Szabó, MD, Gyurgyinka Gergev, MA, Jenő Kóbor, MD, Edit Bereg, MD, \\ Sándor Túri, MD, PhD, DSc, and László Sztriha, MD, PhD, DSc
}

Data regarding the epidemiology of callosal anomalies are contradictory. We performed a population-based retrospective survey to study the birth prevalence and clinical features of agenesis/hypoplasia of the corpus callosum and accompanying central nervous system and somatic abnormalities in southeastern Hungary between July 1, 1992 and June 30, 2006. Among 185,486 live births, 38 patients ( 26 boys and 12 girls) manifested agenesis/hypoplasia of the corpus callosum, corresponding to a prevalence of 2.05 per 10,000 live births (95\% confidence interval, 1.4-2.7). Callosal anomalies were isolated in 18 patients, and were associated with other central nervous system malformations in five children. Both central nervous system and noncentral nervous system abnormalities were evident in seven patients, whereas callosal dysgenesis was accompanied only by somatic anomalies in eight children. Five of $\mathbf{1 8}$ patients with isolated agenesis/hypoplasia of the corpus callosum remained asymptomatic. Developmental delay, intellectual disability, or epilepsy occurred in all patients, except one, when callosal anomalies were combined with other brain or somatic abnormalities. Five patients with multiplex malformations died. Callosal anomalies form a clinically significant and relatively frequent group of central nervous system malformations. (c) 2011 Elsevier Inc. All rights reserved.

Szabó N, Gergev G, Kóbor J, Bereg E, Túri S, Sztriha L. Corpus callosum anomalies: Birth prevalence and clinical spectrum in Hungary. Pediatr Neurol 2011;44:420-426.

\section{Introduction}

The corpus callosum is the largest interhemispheric connective structure in the brain. Callosal abnormalities occur as a result of the failure of fibers to develop or to cross the midline $[1,2]$. The timing of formation of the corpus callosum coincides and overlaps with the occurrence of complex processes involving cellular proliferation and migration, axonal growth, or glial patterning at the midline $[1,2]$. Therefore, malformations of the corpus callosum can occur in a variety of conditions that disrupt early cerebral development, such as intrauterine exposure to teratogens $[1,3]$. Callosal dysgenesis was described in various inborn errors of metabolism [4,5], chromosomal abnormalities [2,6], and syndromes [1,6-10]. Abnormalities of the corpus callosum are often part of complex telencephalic or posterior fossa malformations leading to cerebral palsy $[10,11]$, and they are often associated with somatic malformations outside the central nervous system $[1,6]$.

Callosal anomalies are the most frequent malformations in the brain, with an estimated prevalence as high as $2.3 \%$ in developmentally disabled individuals [12]. Recently, the prevalence of these malformations was determined to be $0.25 \%$ among patients undergoing cranial magnetic resonance imaging at a tertiary care referral institution [13]. A population-based survey, however, indicated that the combined prevalence of agenesis and hypoplasia of the corpus callosum before age 1 year was only 1.8 per 10,000 live births [14].

This study sought to describe the birth prevalence, accompanying abnormalities, and clinical features of patients with callosal anomalies in a region of Hungary.

\section{Patients and Methods}

All children in Hungary are assigned to a pediatrician and his or her clinic. Therefore, children born with anomalies of the corpus callosum in the southeastern region (Dél-Alföld, or South Great Plain) of Hungary between July 1, 1992 and June 30, 2006 were ascertained by searching the databases of pediatric clinics. All pediatricians in the region received
From the Department of Pediatrics, Faculty of Medicine, University of Szeged, Szeged, Hungary.
Communications should be addressed to:

Dr. Sztriha; Department of Pediatrics, Faculty of Medicine; University of Szeged; Temesvári krt. 35-37; Szeged H-6726, Hungary. E-mail: sztriha@pedia.szote.u-szeged.hu Received October 10, 2010; accepted January 17, 2011. 


\title{
Corpus Callosum Anomalies: Birth Prevalence and Clinical Spectrum in Hungary
}

\author{
Nóra Szabó, MD, Gyurgyinka Gergev, MA, Jenő Kóbor, MD, Edit Bereg, MD, \\ Sándor Túri, MD, PhD, DSc, and László Sztriha, MD, PhD, DSc
}

Data regarding the epidemiology of callosal anomalies are contradictory. We performed a population-based retrospective survey to study the birth prevalence and clinical features of agenesis/hypoplasia of the corpus callosum and accompanying central nervous system and somatic abnormalities in southeastern Hungary between July 1, 1992 and June 30, 2006. Among 185,486 live births, 38 patients ( 26 boys and 12 girls) manifested agenesis/hypoplasia of the corpus callosum, corresponding to a prevalence of 2.05 per 10,000 live births (95\% confidence interval, 1.4-2.7). Callosal anomalies were isolated in 18 patients, and were associated with other central nervous system malformations in five children. Both central nervous system and noncentral nervous system abnormalities were evident in seven patients, whereas callosal dysgenesis was accompanied only by somatic anomalies in eight children. Five of 18 patients with isolated agenesis/hypoplasia of the corpus callosum remained asymptomatic. Developmental delay, intellectual disability, or epilepsy occurred in all patients, except one, when callosal anomalies were combined with other brain or somatic abnormalities. Five patients with multiplex malformations died. Callosal anomalies form a clinically significant and relatively frequent group of central nervous system malformations. (c) 2011 Elsevier Inc. All rights reserved.

Szabó N, Gergev G, Kóbor J, Bereg E, Túri S, Sztriha L. Corpus callosum anomalies: Birth prevalence and clinical spectrum in Hungary. Pediatr Neurol 2011;44:420-426.

\section{Introduction}

The corpus callosum is the largest interhemispheric connective structure in the brain. Callosal abnormalities occur as a result of the failure of fibers to develop or to cross the midline $[1,2]$. The timing of formation of the corpus callosum coincides and overlaps with the occurrence of complex processes involving cellular proliferation and migration, axonal growth, or glial patterning at the midline $[1,2]$. Therefore, malformations of the corpus callosum can occur in a variety of conditions that disrupt early cerebral development, such as intrauterine exposure to teratogens $[1,3]$. Callosal dysgenesis was described in various inborn errors of metabolism [4,5], chromosomal abnormalities [2,6], and syndromes [1,6-10]. Abnormalities of the corpus callosum are often part of complex telencephalic or posterior fossa malformations leading to cerebral palsy $[10,11]$, and they are often associated with somatic malformations outside the central nervous system $[1,6]$.

Callosal anomalies are the most frequent malformations in the brain, with an estimated prevalence as high as $2.3 \%$ in developmentally disabled individuals [12]. Recently, the prevalence of these malformations was determined to be $0.25 \%$ among patients undergoing cranial magnetic resonance imaging at a tertiary care referral institution [13]. A population-based survey, however, indicated that the combined prevalence of agenesis and hypoplasia of the corpus callosum before age 1 year was only 1.8 per 10,000 live births [14].

This study sought to describe the birth prevalence, accompanying abnormalities, and clinical features of patients with callosal anomalies in a region of Hungary.

\section{Patients and Methods}

All children in Hungary are assigned to a pediatrician and his or her clinic. Therefore, children born with anomalies of the corpus callosum in the southeastern region (Dél-Alföld, or South Great Plain) of Hungary between July 1, 1992 and June 30, 2006 were ascertained by searching the databases of pediatric clinics. All pediatricians in the region received
From the Department of Pediatrics, Faculty of Medicine, University of Szeged, Szeged, Hungary.
Communications should be addressed to:

Dr. Sztriha; Department of Pediatrics, Faculty of Medicine; University of Szeged; Temesvári krt. 35-37; Szeged H-6726, Hungary.

E-mail: sztriha@pedia.szote.u-szeged.hu

Received October 10, 2010; accepted January 17, 2011. 
questionnaires and were requested to report on patients with anomalies of the corpus callosum. In addition, they were encouraged by telephone interviews and field researchers to provide information on these patients, to compile as complete a register as possible. Demographic data were collected from the Hungarian Central Statistical Office.

The diagnosis of corpus callosum anomalies was established by cranial ultrasound and magnetic resonance imaging, in all cases performed using conventional protocols. Magnetic resonance images were reviewed visually by two examiners (N.S. and L.S.) independently. The types and severity of commissural anomalies, the presence and types of malformations of the cerebral cortex, cerebellum, brainstem, and orbits, distortions of the cerebral ventricles, and anomalies of the white matter were evaluated. The size of the corpus callosum was also assessed visually in the sagittal midline, using age-matched normal magnetic resonance images as controls, and a diagnosis of hypoplasia of the corpus callosum established when examiners reached a consensus.

The terminology of callosal anomalies included [1]:

(1) Agenesis: total absence of the corpus callosum;

(2) Partial agenesis (hypogenesis): partial absence of the corpus callosum; and

(3) Hypoplasia: the corpus callosum is fully formed, but is thinner than expected for the age of the individual (and contains too few axons).

A detailed analysis of patients with anomalies of the corpus callosum was performed. Clinical records were retrospectively reviewed for family history, parental consanguinity, maternal and birth history, possible environmental factors, neonatal course, developmental milestones, and epileptic seizures. Detailed clinical and neurologic examinations were performed. Dysmorphic features and noncentral nervous system malformations received special attention. A chromosomal analysis was requested for patients with dysmorphic features or multiple anomalies. Electroencephalography was performed on epileptic patients, according to the international 10-20 system of electrode placement.

On the basis of the accompanying central nervous system or noncentral nervous system malformations, patients were classified into four groups:

Group 1: Isolated agenesis/hypoplasia of the corpus callosum.

Confounding central nervous system or noncentral nervous system abnormalities were not evident. Colpocephaly (dilatation of the posterior aspect of the lateral ventricles), Probst bundles (misrouted callosal axons that run parallel to the interhemispheric fissure), and temporal horn abnormalities with malrotated hippocampus and interhemispheric cysts, if present, were regarded as part of the isolated corpus callosum abnormality complex, and not as an accompanying malformation.

Group 2: Agenesis/hypoplasia of the corpus callosum associated with other central nervous system abnormalities. From this group we excluded patients with complex central nervous system malformations (e.g., lissencephaly, holoprosencephaly, or bilateral schizencephaly), in which the callosal malformation is thought to be secondary to the principal malformation.

Group 3: Agenesis/hypoplasia of the corpus callosum associated with both central nervous system and noncentral nervous system abnormalities.

Group 4: Agenesis/hypoplasia of the corpus callosum associated only with noncentral nervous system abnormalities.

Patients with anomalies of the corpus callosum secondary to destructive events (hypoxic-ischemic encephalopathy, injuries, intracranial hemorrhage, or any known environmental factors) were excluded from the study. Preterm infants with a thin corpus callosum in association with periventricular leukomalacia were also excluded.

We calculated the birth prevalence of corpus callosum anomalies per 10,000 live births in the region between July 1, 1992 and June 30, 2006. The numerator comprised the total number of live births with anomalies of the corpus callosum, and the denominator comprised the total number of live births during the same period.

Statistical analysis was performed using SPSS, version 15.0 (SPSS, Inc., Chicago, IL). We calculated $95 \%$ confidence intervals on the basis of approximation to the binomial distribution.

This study was approved by the Ethics Committee of the Faculty of Medicine, University of Szeged (Szeged, Hungary). Informed consent was requested from the parents of patients before participation in the study.

\section{Results}

In the area under study, $185,486(95,241$ male and 90,245 female) live births occurred between July 1, 1992 and June 30,2006. The number of patients born with an anomaly of the corpus callosum totaled 38 ( 26 boys and 12 girls) during the study period. Total or partial agenesis occurred in 19 patients ( 13 boys and 6 girls), whereas hypoplasia of the corpus callosum was also evident in 19 patients ( 13 boys and 6 girls). The epidemiologic results are summarized in Table 1. The overall birth prevalence of total or partial agenesis and hypoplasia involved 2.05 per 10,000 live births (95\% confidence interval, 1.4-2.7), including 2.73 per 10,000 among boys ( $95 \%$ confidence interval, $1.68-3.78)$, and 1.33 per 10,000 among girls $(95 \%$ confidence interval, $0.58-2.08$ ). The birth prevalence of total and partial agenesis of the corpus callosum involved 1.02 per 10,000 live births ( $95 \%$ confidence interval, $0.56-1.48$ ), with 1.36 per 10,000 among boys ( $95 \%$ confidence interval, $0.62-2.11$ ), and 0.66 per 10,000 among girls (95\% confidence interval, 0.13-1.20). The birth prevalence of hypoplasia of the corpus callosum involved 1.02 per 10,000 live births (95\% confidence interval, 0.56-1.48), with 1.36 per 10,000 among boys ( $95 \%$ confidence interval, $0.62-2.11$ ), and 0.66 per 10,000 among girls ( $95 \%$ confidence interval, 0.13-1.20). The male/female sex ratio was 2.2 for both total or partial agenesis and hypoplasia of the corpus callosum (Table 1). No parental consanguinity or familial occurrence of corpus callosum anomalies occurred.

Isolated agenesis/hypoplasia of the corpus callosum was evident in 18 patients (Group 1; Table 2). Delayed development, intellectual disability, and epilepsy occurred in several patients of this group (Table 2). Abnormal neurologic findings were evident in only two children.

Agenesis/hypoplasia of the corpus callosum was associated with another central nervous system malformation without noncentral nervous system malformations in five children (Group 2; Table 3). The callosal anomaly was accompanied by microcephaly, optic nerve hypoplasia, cerebellar vermis hypoplasia, or wide cavum septum pellucidum (Table 3). Developmental delay and intellectual disability were evident in four patients, abnormal neurologic findings were evident in three patients, and epilepsy was diagnosed in two children of this group.

Both central nervous system and noncentral nervous system abnormalities accompanied agenesis/hypoplasia of the corpus callosum in seven patients (Group 3; Table 4). Callosal anomalies were associated with encephalocele, hemimegalencephaly, polymicrogyria, cortical dysplasia, or wide cavum septum pellucidum in addition to noncentral nervous system abnormalities, such as dysmorphic features, congenital heart disease, limb anomalies, or hip dysplasia (Table 4). Delayed development, intellectual 


\begin{tabular}{|c|c|c|c|c|}
\hline $\begin{array}{c}\text { Corpus Callosum } \\
\text { Anomaly }\end{array}$ & $\begin{array}{c}\text { Overall Prevalence } \\
\text { per } 10,000 \\
\text { Live Births }\end{array}$ & $\begin{array}{l}\text { Prevalence for } \\
\text { Males per } 10,000 \\
\text { Live Births }\end{array}$ & $\begin{array}{l}\text { Prevalence for } \\
\text { Females per 10,000 } \\
\text { Live Births }\end{array}$ & $\begin{array}{c}\text { Sex Ratio } \\
\text { (Male/Female) }\end{array}$ \\
\hline $\begin{array}{l}\text { Agenesis (total and partial) } \\
\text { and hypoplasia }\end{array}$ & $\begin{array}{l}2.05 \text { (95\% confidence } \\
\text { interval, 1.4-2.7) }\end{array}$ & $\begin{array}{r}2.73 \text { (95\% confidence } \\
\text { interval, } 1.68-3.78)\end{array}$ & $\begin{array}{r}1.33(95 \% \text { confidence } \\
\text { interval, } 0.58-2.08)\end{array}$ & 2.2 \\
\hline Agenesis (total and partial) & $\begin{array}{r}1.02(95 \% \text { confidence } \\
\text { interval, } 0.56-1.48)\end{array}$ & $\begin{array}{c}1.36(95 \% \text { confidence } \\
\text { interval, } 0.62-2.11)\end{array}$ & $\begin{array}{r}0.66(95 \% \text { confidence } \\
\text { interval, } 0.13-1.20)\end{array}$ & 2.2 \\
\hline Hypoplasia & $\begin{array}{r}1.02 \text { ( } 95 \% \text { confidence } \\
\text { interval, } 0.56-1.48)\end{array}$ & $\begin{array}{r}1.36(95 \% \text { confidence } \\
\text { interval, } 0.62-2.11)\end{array}$ & $\begin{array}{r}0.66(95 \% \text { confidence } \\
\text { interval, } 0.13-1.20)\end{array}$ & 2.2 \\
\hline
\end{tabular}

disability, and abnormal neurologic findings were evident in all patients, and epilepsy was diagnosed in three children of this group.

Thus, callosal anomalies were associated with other central nervous system malformations in 12 out of 38 children (Groups 2 and 3; Tables 3 and 4). An interhemispheric cyst, regarded as a frequent part of the callosal anomaly complex, was evident in five children (Groups 1 and 3; Table 2 and 4).

Callosal anomalies were associated with abnormalities only outside the central nervous system in eight patients (Group 4; Table 5). Four infants died during the neonatal period, and autopsies confirmed the callosal and noncentral nervous system abnormalities. Short ribpolydactyly syndrome type II (Majewski; Patient 2) and chromosome 18 trisomy (Edwards syndrome; Patient 4) were classified in this group, because agenesis of the corpus callosum was the only central nervous system malformation in these patients, accompanying the numerous noncentral nervous system abnormalities. Developmental delay and intellectual disability were evident in patients surviving the neonatal period, and three of these four children demonstrated abnormal neurologic findings or epilepsy.

Table 2. Group 1: Isolated agenesis/hypoplasia of the corpus callosum

\begin{tabular}{|c|c|c|c|c|c|c|c|c|}
\hline Patient & Sex & Age* & $\begin{array}{c}\text { CC } \\
\text { Malformation }\end{array}$ & $\begin{array}{l}\text { Developmental } \\
\text { Delay }\end{array}$ & $\begin{array}{l}\text { Intellectual } \\
\text { Disability }\end{array}$ & $\begin{array}{l}\text { Neurologic } \\
\text { Findings }\end{array}$ & Epilepsy & Comments \\
\hline 1 & M & $14 \mathrm{yr}$ & Agenesis & + & + & - & + & \\
\hline 2 & M & $6 \mathrm{yr}$ & Agenesis & + & - & - & + & \\
\hline 3 & M & $6 \mathrm{yr}$ & Agenesis & + & - & Generalized hypotonia & - & \\
\hline 4 & M & $4 \mathrm{yr}$ & Agenesis & + & - & - & + & \\
\hline 5 & M & $11 \mathrm{yr}$ & $\begin{array}{l}\text { Agenesis } \\
\text { Interhemispheric cyst }\end{array}$ & - & - & - &. & Prenatal diagnosis \\
\hline 6 & M & $7 \mathrm{yr}$ & $\begin{array}{l}\text { Agenesis } \\
\text { Interhemispheric cyst }\end{array}$ & - & - & - & - & Prenatal diagnosis \\
\hline 7 & M & $13 \mathrm{yr}$ & Hypoplasia & + & + & - & + & \\
\hline 8 & M & $10 \mathrm{yr}$ & Hypoplasia & - & - & - & + & \\
\hline 9 & M & $10 \mathrm{yr}$ & Hypoplasia & + & + & Cerebral palsy: spastic tetraplegia & + & \\
\hline 10 & M & $7 \mathrm{yr}$ & Hypoplasia & + & + & - & - & \\
\hline 11 & $\mathrm{~F}$ & $6 \mathrm{yr}$ & Hypoplasia & + & + & - & - & \\
\hline 12 & $\mathrm{~F}$ & $6 \mathrm{yr}$ & Hypoplasia & + & + & - & + & \\
\hline 13 & M & $5 \mathrm{yr}$ & Hypoplasia & + & + & - & + & \\
\hline 14 & $\mathrm{~F}$ & $2 \mathrm{yr}$ & Hypoplasia & + & - & - & - & \\
\hline 15 & $\mathrm{~F}$ & $1 \mathrm{yr}$ & Hypoplasia & - & - & - & + & \\
\hline 16 & M & $1 \mathrm{yr}$ & Hypoplasia & - & - & - & - & Prenatal diagnosis \\
\hline 17 & M & $3 \mathrm{yr}$ & $\begin{array}{l}\text { Hypoplasia } \\
\text { Interhemispheric cyst }\end{array}$ & - & - & - & - & Prenatal diagnosis \\
\hline 18 & M & $1 \mathrm{yr}$ & $\begin{array}{l}\text { Hypoplasia } \\
\text { Interhemispheric cyst }\end{array}$ & - & - & - & - & Prenatal diagnosis \\
\hline$*$ Age & ost & $n t \mathrm{fc}$ & ow-up. & & & & & \\
\hline $\begin{array}{l}\text { Abbrevia } \\
\mathrm{CC}=\mathrm{C} \\
\mathrm{F}=\mathrm{F} \\
\mathrm{M}=\mathrm{N} \\
\mathrm{yr}=\mathrm{Y}\end{array}$ & $\begin{array}{l}\text { tions: } \\
\text { orpus c } \\
\text { emale } \\
\text { ale } \\
\text { cars }\end{array}$ & allosum & & & & . & & \\
\hline
\end{tabular}




\begin{tabular}{|c|c|c|c|c|}
\hline $\begin{array}{c}\text { Corpus Callosum } \\
\text { Anomaly }\end{array}$ & $\begin{array}{c}\text { Overall Prevalence } \\
\text { per } 10,000 \\
\text { Live Births }\end{array}$ & $\begin{array}{l}\text { Prevalence for } \\
\text { Males per } 10,000 \\
\text { Live Births }\end{array}$ & $\begin{array}{c}\text { Prevalence for } \\
\text { Females per 10,000 } \\
\text { Live Births }\end{array}$ & $\begin{array}{c}\text { Sex Ratio } \\
\text { (Male/Female) }\end{array}$ \\
\hline $\begin{array}{l}\text { Agenesis (total and partial) } \\
\text { and hypoplasia }\end{array}$ & $\begin{array}{c}2.05(95 \% \text { confidence } \\
\text { interval, } 1.4-2.7)\end{array}$ & $\begin{array}{r}2.73 \text { (95\% confidence } \\
\text { interval, } 1.68-3.78)\end{array}$ & $\begin{array}{r}1.33 \text { (95\% confidence } \\
\text { interval, } 0.58-2.08)\end{array}$ & 2.2 \\
\hline Agenesis (total and partial) & $\begin{array}{r}1.02(95 \% \text { confidence } \\
\text { interval, } 0.56-1.48)\end{array}$ & $\begin{array}{r}1.36 \text { ( } 95 \% \text { confidence } \\
\text { interval, } 0.62-2.11)\end{array}$ & $\begin{array}{r}0.66 \text { ( } 95 \% \text { confidence } \\
\text { interval, } 0.13-1.20)\end{array}$ & 2.2 \\
\hline Hypoplasia & $\begin{array}{r}1.02(95 \% \text { confidence } \\
\text { interval, } 0.56-1.48)\end{array}$ & $\begin{array}{r}1.36(95 \% \text { confidence } \\
\text { interval, } 0.62-2.11)\end{array}$ & $\begin{array}{r}0.66(95 \% \text { confidence } \\
\text { interval, } 0.13-1.20)\end{array}$ & 2.2 \\
\hline
\end{tabular}

disability, and abnormal neurologic findings were evident in all patients, and epilepsy was diagnosed in three children of this group.

Thus, callosal anomalies were associated with other central nervous system malformations in 12 out of 38 children (Groups 2 and 3; Tables 3 and 4). An interhemispheric cyst, regarded as a frequent part of the callosal anomaly complex, was evident in five children (Groups 1 and 3; Table 2 and 4).

Callosal anomalies were associated with abnormalities only outside the central nervous system in eight patients (Group 4; Table 5). Four infants died during the neonatal period, and autopsies confirmed the callosal and noncentral nervous system abnormalities. Short ribpolydactyly syndrome type II (Majewski; Patient 2) and chromosome 18 trisomy (Edwards syndrome; Patient 4) were classified in this group, because agenesis of the corpus callosum was the only central nervous system malformation in these patients, accompanying the numerous noncentral nervous system abnormalities. Developmental delay and intellectual disability were evident in patients surviving the neonatal period, and three of these four children demonstrated abnormal neurologic findings or epilepsy.

Table 2. Group 1: Isolated agenesis/hypoplasia of the corpus callosum

\begin{tabular}{|c|c|c|c|c|c|c|c|c|}
\hline Patient & Sex & Age* $^{*}$ & $\begin{array}{c}\text { CC } \\
\text { Malformation }\end{array}$ & $\begin{array}{c}\text { Developmental } \\
\text { Delay }\end{array}$ & $\begin{array}{l}\text { Intellectual } \\
\text { Disability }\end{array}$ & $\begin{array}{l}\text { Neurologic } \\
\text { Findings }\end{array}$ & Epilepsy & Comments \\
\hline 1 & M & $14 \mathrm{yr}$ & Agenesis & + & + & - & + & \\
\hline 2 & M & $6 \mathrm{yr}$ & Agenesis & + & - & - & + & \\
\hline 3 & M & $6 \mathrm{yr}$ & Agenesis & + & - & Generalized hypotonia & - & \\
\hline 4 & M & $4 \mathrm{yr}$ & Agenesis & + & - & - & + & \\
\hline 5 & M & $11 \mathrm{yr}$ & $\begin{array}{l}\text { Agenesis } \\
\text { Interhemispheric cyst }\end{array}$ & - & - & - & - & Prenatal diagnosis \\
\hline 6 & $\mathrm{M}$ & $7 \mathrm{yr}$ & $\begin{array}{l}\text { Agenesis } \\
\text { Interhemispheric cyst }\end{array}$ & - & - & - & - & Prenatal diagnosis \\
\hline 7 & M & $13 \mathrm{yr}$ & Hypoplasia & + & + & - & + & \\
\hline 8 & M & $10 \mathrm{yr}$ & Hypoplasia & - & - & - & + & \\
\hline 9 & M & $10 \mathrm{yr}$ & Hypoplasia & + & + & Cerebral palsy: spastic tetraplegia & + & \\
\hline 10 & M & $7 \mathrm{yr}$ & Hypoplasia & + & + & - & - & \\
\hline 11 & $\mathrm{~F}$ & $6 \mathrm{yr}$ & Hypoplasia & + & + & - & - & \\
\hline 12 & $\mathrm{~F}$ & $6 \mathrm{yr}$ & Hypoplasia & + & + & - & + & \\
\hline 13 & M & $5 \mathrm{yr}$ & Hypoplasia & + & + & - & + & \\
\hline 14 & $\mathrm{~F}$ & $2 \mathrm{yr}$ & Hypoplasia & + & - & - & - & \\
\hline 15 & $\mathrm{~F}$ & $1 \mathrm{yr}$ & Hypoplasia & - & - & - & + & \\
\hline 16 & M & $1 \mathrm{yr}$ & Hypoplasia & - & - & - & - & Prenatal diagnosis \\
\hline 17 & M & $3 \mathrm{yr}$ & $\begin{array}{l}\text { Hypoplasia } \\
\text { Interhemispheric cyst }\end{array}$ & - & - & - & - & Prenatal diagnosis \\
\hline 18 & M & $1 \mathrm{yr}$ & $\begin{array}{l}\text { Hypoplasia } \\
\text { Interhemispheric cyst }\end{array}$ & - & - & - & - & Prenatal diagnosis \\
\hline * Age : & st & to & v-up. & & & & & \\
\hline $\begin{array}{l}\text { Abbrevia } \\
\mathrm{CC}=\mathrm{C} \\
\mathrm{F}=\mathrm{F} \\
\mathrm{M}=\mathrm{M} \\
\mathrm{yr}=\mathrm{Y}\end{array}$ & $\begin{array}{l}\text { ions: } \\
\text { orpus c } \\
\text { male } \\
\text { ale } \\
\text { ars }\end{array}$ & allosum & & & & . & & \\
\hline
\end{tabular}


Table 3. Group 2: Agenesis/hypoplasia of the corpus callosum in association with other CNS abnormalities

\begin{tabular}{|c|c|c|c|c|c|c|c|c|c|}
\hline Patient & Sex & Age* & $\begin{array}{c}\mathrm{CC} \\
\text { Malformation }\end{array}$ & $\begin{array}{l}\text { Associated CNS } \\
\text { Abnormalities }\end{array}$ & $\begin{array}{l}\text { Developmental } \\
\text { Delay }\end{array}$ & $\begin{array}{l}\text { Intellectual } \\
\text { Disability }\end{array}$ & $\begin{array}{l}\text { Neurologic } \\
\text { Findings }\end{array}$ & Epilepsy & Comments \\
\hline 1 & $\mathrm{~F}$ & $12 \mathrm{yr}$ & Agenesis & Microcephaly & + & + & $\begin{array}{l}\text { Axial hypotonia } \\
\text { Nystagmus }\end{array}$ & - & \\
\hline 2 & M & $10 \mathrm{yr}$ & Agenesis & $\begin{array}{l}\text { Bilateral optic nerve } \\
\text { hypoplasia }\end{array}$ & + & + & $\begin{array}{l}\text { Cerebral palsy: } \\
\text { spastic tetraplegia }\end{array}$ & + & \\
\hline 3 & $\mathrm{~F}$ & $3 \mathrm{yr}$ & $\begin{array}{l}\text { Partial agenesis } \\
\text { (rostrum is } \\
\text { absent) }\end{array}$ & $\begin{array}{l}\text { Cerebellar vermis } \\
\text { hypoplasia } \\
\text { (no molar tooth } \\
\text { malformation) }\end{array}$ & + & + & - & + & \\
\hline 4 & M & $10 \mathrm{yr}$ & Hypoplasia & $\begin{array}{l}\text { Wide cavum septum } \\
\text { pellucidum }\end{array}$ & - & - & - & - & $\begin{array}{l}\text { MRI because } \\
\text { of headache }\end{array}$ \\
\hline 5 & M & $4 \mathrm{yr}$ & Hypoplasia & $\begin{array}{l}\text { Microcephaly } \\
\text { Bilateral optic nerve } \\
\text { hypoplasia }\end{array}$ & + & + & $\begin{array}{l}\text { Cerebral palsy: spastic } \\
\text { tetraplegia }\end{array}$ & - & \\
\hline \multicolumn{10}{|c|}{ * Age at most recent follow-up. } \\
\hline $\begin{array}{l}\text { Abbrevia } \\
\mathrm{CC}= \\
\mathrm{CNS}= \\
\mathrm{F}= \\
\mathrm{M}= \\
\mathrm{MRI}= \\
\mathrm{yr}=\end{array}$ & $\begin{array}{l}\text { ations: } \\
\text { Corpu } \\
\text { Centra } \\
\text { Femal } \\
\text { Male } \\
\text { Magne } \\
\text { Years }\end{array}$ & $\begin{array}{l}\text { callosu } \\
\text { nervou }\end{array}$ & $\begin{array}{l}\text { m } \\
\text { system } \\
\text { ance imaging }\end{array}$ & & & & & & \\
\hline
\end{tabular}

Noncentral nervous system abnormalities were evident in 15 of the total 38 patients with callosal anomalies (Groups 3 and 4; Tables 4 and 5).

\section{Discussion}

The birth prevalence of callosal anomalies (complete or partial agenesis and hypoplasia of the corpus callosum) comprised 2.05 per 10,000 live births in southeastern Hungary (Table 1). This result is very similar to the birth prevalence of 1.8 per 10,000 ascertained in California by a population-based survey that included infants aged less than 1 year [14]. Our figure is slightly higher, however, because all children with callosal anomalies born in a 14-year period between July 1, 1992 and June 30, 2006 were included in our survey, regardless of age at time of diagnosis. This slight difference suggests that the majority of callosal anomalies are recognized in infancy, mainly prenatally or during the newborn period [14].

Similar to the procedure in previous studies $[6,14]$, both agenesis (total and partial) and hypoplasia were included in our survey, because these two conditions may be linked by a common genetic defect [15]. Total or partial agenesis was evident in exactly half of the patients in this study, whereas hypoplasia was evident in the other $50 \%$ of cases (the agenesis/hypoplasia ratio was 1; Table 1). The agenesis/hypoplasia ratio comprised 1.25 in another retrospective study by Schell-Apacik et al. [6], but almost reached 3 in the California-based study [14]. We found a male predominance among patients with callosal anomalies in Hungary (Table 1). The sex distribution was almost equal in the
California study, with only a slight, nonsignificant predominance of the male sex [14]. However, a more prominent male predominance was reported by others for total or partial agenesis of the corpus callosum [6,13]. A male/female sex ratio of 2.3 was described by Chadie et al. [16], a figure very close to the ratio of 2.2 in the present survey (Table 1 ).

Isolated agenesis, or hypoplasia of the corpus callosum, may on occasion be entirely asymptomatic (Group 1; Table 2) according to routine clinical assessment [16]. However, sophisticated psychometric testing, which was not performed in our patients, would probably have revealed social deficits or problems with visual processing and higher-order language functions, even in patients thought to be asymptomatic [17-19]. Clinical signs, such as developmental delay, intellectual disability, or epilepsy, are frequent manifestations of isolated agenesis or hypoplasia of the corpus callosum [16,20,21], and indeed 13 out of 18 patients with isolated callosal anomalies in our survey were symptomatic (Group 1; Table 2).

In a number of cases, callosal abnormalities occurred with other central nervous system anomalies (Groups 2 and 3; Tables 3 and 4). The combination of microcephaly and callosal anomalies in two patients of this series may indicate a common genetic background [15,22]. Malformations of cortical development (hemimegalencephaly with agyria-pachygyria, polymicrogyria, and cortical dysplasia) occurred in only four of 38 patients in our study, but were more frequent in previous series of patients with total or partial agenesis of the corpus callosum $[6,13,23]$. Cerebellar vermis hypoplasia was evident in 


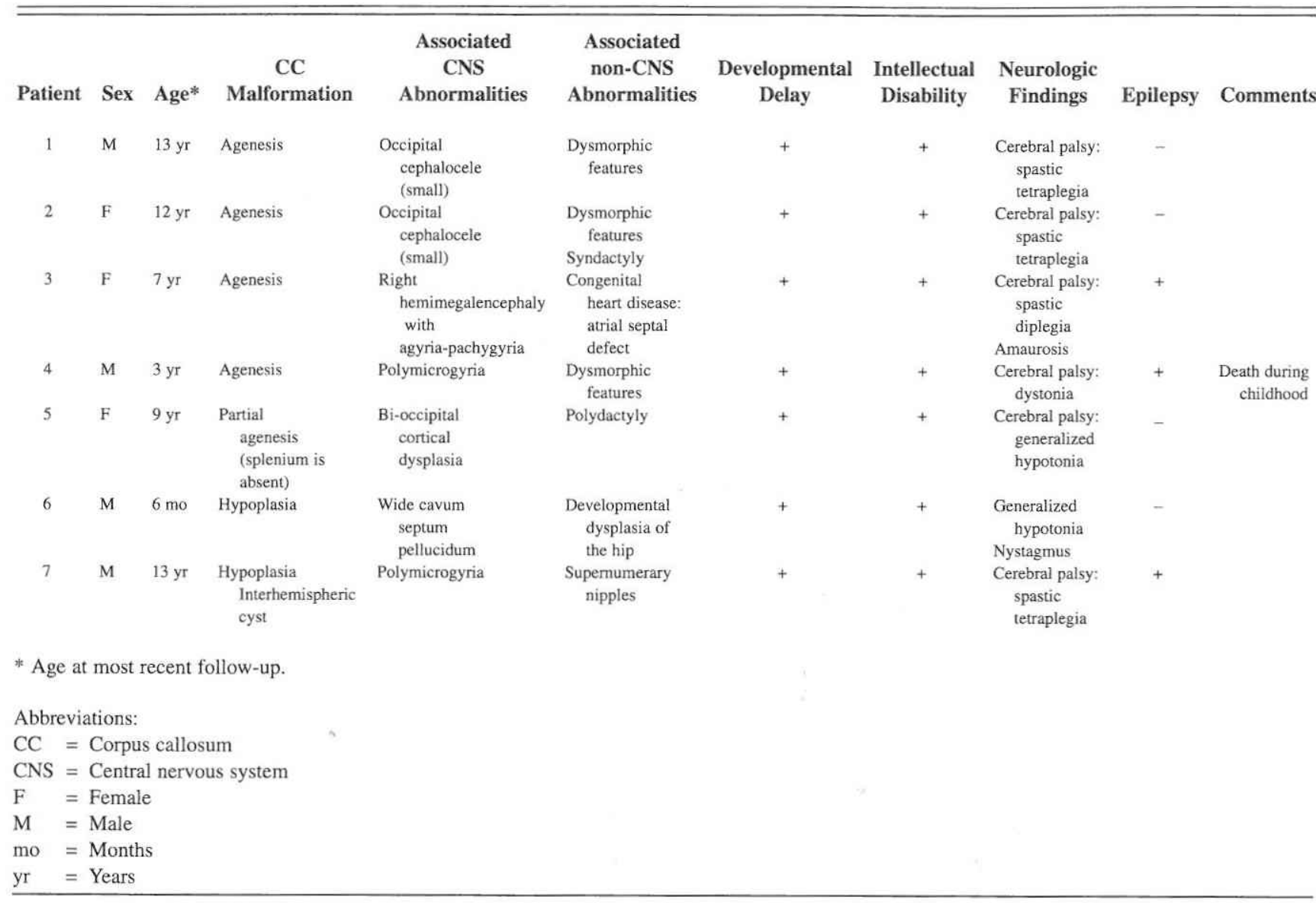

only one patient of our series, in contrast to the one third of patients with agenesis in the large cohort described by Hetts et al. [13]. However, our inclusion criteria differed from those of Hetts et al. [13], who surveyed mainly symptomatic patients, contrary to our population-based inclusion criteria. Interestingly, interhemispheric cysts occurred to the same extent in our survey as in the study by Hetts et al. [13], i.e., one seventh of patients demonstrated this abnormality. Interhemispheric lipoma was not evident in our patients.

The association of corpus callosum hypoplasia and optic nerve hypoplasia may predict poor outcomes in all developmental domains, and an increased risk of delay [24]. Indeed, our two patients with the combination of optic nerve hypoplasia and callosal anomalies demonstrated developmental delay, intellectual disability, and spastic tetraplegia (Patients 2 and 5, Group 2; Table 3). The association of callosal agenesis and cephalocele (Patients 1 and 2, Group 3; Table 4) is common [25]. A wide cavum septum pellucidum was regarded as a malformation (Patient 4, Group 2, Table 3; Patient 6, Group 3, Table 4). An earlier study suggested that a wide cavum septum pellucidum may indicate disturbed brain development, and may represent part of a spectrum of midline brain anomalies in association with hypoplasia of the corpus callosum and cognitive impairment [26].
Callosal anomalies are features of several syndromes with various inheritance patterns [1,6-10]. In a previous survey, agenesis of the corpus callosum proved to be a feature of a well-defined syndrome in four among 41 patients [6]. In our series (Patient 2, Group 4; Table 5), only a single case with the combination of callosal anomaly and a recognizable syndrome occurred: the corpus callosum was absent in a patient with short rib-polydactyly syndrome, type II (Majewski). Agenesis of the corpus callosum in association with an atypical form of short rib-polydactyly syndrome and callosal hypoplasia combined with short rib-polydactyly syndrome, Majewski type, were described previously $[27,28]$.

Abnormalities of the corpus callosum were evident in trisomies and in some chromosomal rearrangements, suggesting that causative genes may be located in these affected chromosomal regions $[2,6]$. In a previous study, chromosomal changes were discovered in eight of 41 patients [6]. A single patient with a chromosomal abnormality (trisomy 18, Patient 4, Group 4; Table 5) was evident in our case series of 38 children. However, subtelomeric analyses and microarray-based comparative genomic hybridization [29] were not available for our patients.

The birth prevalence and clinical spectrum of callosal anomalies in southeastern Hungary were surveyed in this 


\begin{tabular}{|c|c|c|c|c|c|c|c|c|c|c|}
\hline Patient & Sex & Age* & $\begin{array}{c}\mathrm{CC} \\
\text { Malformation }\end{array}$ & $\begin{array}{c}\text { Associated } \\
\text { CNS } \\
\text { Abnormalities }\end{array}$ & $\begin{array}{c}\text { Associated } \\
\text { non-CNS } \\
\text { Abnormalities }\end{array}$ & $\begin{array}{c}\text { Developmental } \\
\text { Delay }\end{array}$ & $\begin{array}{l}\text { Intellectual } \\
\text { Disability }\end{array}$ & $\begin{array}{l}\text { Neurologic } \\
\text { Findings }\end{array}$ & Epilepsy & Comments \\
\hline 1 & M & $13 \mathrm{yr}$ & Agenesis & $\begin{array}{l}\text { Occipital } \\
\text { cephalocele } \\
\text { (small) }\end{array}$ & $\begin{array}{c}\text { Dysmorphic } \\
\text { features }\end{array}$ & + & + & $\begin{array}{l}\text { Cerebral palsy: } \\
\text { spastic } \\
\text { tetraplegia }\end{array}$ & - & \\
\hline 2 & $\mathrm{~F}$ & $12 \mathrm{yr}$ & Agenesis & $\begin{array}{l}\text { Occipital } \\
\text { cephalocele } \\
\text { (small) }\end{array}$ & $\begin{array}{c}\text { Dysmorphic } \\
\text { features } \\
\text { Syndactyly }\end{array}$ & + & + & $\begin{array}{l}\text { Cerebral palsy: } \\
\text { spastic } \\
\text { tetraplegia }\end{array}$ & - & \\
\hline 3 & $\mathrm{~F}$ & $7 \mathrm{yr}$ & Agenesis & $\begin{array}{l}\text { Right } \\
\text { hemimegalencephaly } \\
\text { with } \\
\text { agyria-pachygyria }\end{array}$ & $\begin{array}{l}\text { Congenital } \\
\text { heart disease: } \\
\text { atrial septal } \\
\text { defect }\end{array}$ & + & + & $\begin{array}{l}\text { Cerebral palsy: } \\
\text { spastic } \\
\text { diplegia } \\
\text { Amaurosis }\end{array}$ & + & \\
\hline 4 & M & $3 \mathrm{yr}$ & Agenesis & Polymicrogyria & $\begin{array}{c}\text { Dysmorphic } \\
\text { features }\end{array}$ & + & + & $\begin{array}{l}\text { Cerebral palsy: } \\
\text { dystonia }\end{array}$ & + & $\begin{array}{r}\text { Death during } \\
\text { childhood }\end{array}$ \\
\hline 5 & $\mathrm{~F}$ & $9 \mathrm{yr}$ & $\begin{array}{l}\text { Partial } \\
\text { agenesis } \\
\text { (splenium is } \\
\text { absent) }\end{array}$ & $\begin{array}{c}\text { Bi-occipital } \\
\text { cortical } \\
\text { dysplasia }\end{array}$ & Polydactyly & + & + & $\begin{array}{l}\text { Cerebral palsy: } \\
\text { generalized } \\
\text { hypotonia }\end{array}$ & - & \\
\hline 6 & M & $6 \mathrm{mo}$ & Hypoplasia & $\begin{array}{l}\text { Wide cavum } \\
\text { septum } \\
\text { pellucidum }\end{array}$ & $\begin{array}{l}\text { Developmental } \\
\text { dysplasia of } \\
\text { the hip }\end{array}$ & + & + & $\begin{array}{l}\text { Generalized } \\
\text { hypotonia } \\
\text { Nystagmus }\end{array}$ & - & \\
\hline 7 & M & $13 \mathrm{yr}$ & $\begin{array}{l}\text { Hypoplasia } \\
\text { Interhemispheric } \\
\text { cyst }\end{array}$ & Polymicrogyria & $\begin{array}{l}\text { Supernumerary } \\
\text { nipples }\end{array}$ & + & + & $\begin{array}{l}\text { Cerebral palsy: } \\
\text { spastic } \\
\text { tetraplegia }\end{array}$ & + & \\
\hline \multicolumn{11}{|c|}{ * Age at most recent follow-up. } \\
\hline \multicolumn{11}{|c|}{ Abbreviations: } \\
\hline \multicolumn{11}{|c|}{$\mathrm{CC}=$ Corpus callosum } \\
\hline $\mathrm{CNS}=$ & Centra & al nervol & us system & & & & & & & \\
\hline$=$ & Femal & & & & & & & & & \\
\hline$M=$ & Male & & & & & & & & & \\
\hline mo $=$ & Month & & & & & & & & & \\
\hline $\mathrm{yr}$ & Years & & & & & & & & & \\
\hline
\end{tabular}

only one patient of our series, in contrast to the one third of patients with agenesis in the large cohort described by Hetts et al. [13]. However, our inclusion criteria differed from those of Hetts et al. [13], who surveyed mainly symptomatic patients, contrary to our population-based inclusion criteria. Interestingly, interhemispheric cysts occurred to the same extent in our survey as in the study by Hetts et al. [13], i.e., one seventh of patients demonstrated this abnormality. Interhemispheric lipoma was not evident in our patients.

The association of corpus callosum hypoplasia and optic nerve hypoplasia may predict poor outcomes in all developmental domains, and an increased risk of delay [24]. Indeed, our two patients with the combination of optic nerve hypoplasia and callosal anomalies demonstrated developmental delay, intellectual disability, and spastic tetraplegia (Patients 2 and 5, Group 2; Table 3). The association of callosal agenesis and cephalocele (Patients 1 and 2, Group 3; Table 4) is common [25]. A wide cavum septum pellucidum was regarded as a malformation (Patient 4, Group 2, Table 3; Patient 6, Group 3, Table 4). An earlier study suggested that a wide cavum septum pellucidum may indicate disturbed brain development, and may represent part of a spectrum of midline brain anomalies in association with hypoplasia of the corpus callosum and cognitive impairment [26].
Callosal anomalies are features of several syndromes with various inheritance patterns $[1,6-10]$. In a previous survey, agenesis of the corpus callosum proved to be a feature of a well-defined syndrome in four among 41 patients [6]. In our series (Patient 2, Group 4; Table 5), only a single case with the combination of callosal anomaly and a recognizable syndrome occurred: the corpus callosum was absent in a patient with short rib-polydactyly syndrome, type II (Majewski). Agenesis of the corpus callosum in association with an atypical form of short rib-polydactyly syndrome and callosal hypoplasia combined with short rib-polydactyly syndrome, Majewski type, were described previously $[27,28]$.

Abnormalities of the corpus callosum were evident in trisomies and in some chromosomal rearrangements, suggesting that causative genes may be located in these affected chromosomal regions $[2,6]$. In a previous study, chromosomal changes were discovered in eight of 41 patients [6]. A single patient with a chromosomal abnormality (trisomy 18, Patient 4, Group 4; Table 5) was evident in our case series of 38 children. However, subtelomeric analyses and microarray-based comparative genomic hybridization [29] were not available for our patients.

The birth prevalence and clinical spectrum of callosal anomalies in southeastern Hungary were surveyed in this 
Table 5. Group 4: Agenesis/hypoplasia of the corpus callosum in association with non-CNS abnormalities

\begin{tabular}{|c|c|c|c|c|c|c|c|c|c|}
\hline Patient & Sex & Age* & $\begin{array}{c}\mathrm{CC} \\
\text { Malformation }\end{array}$ & $\begin{array}{l}\text { Associated non-CNS } \\
\text { Abnormalities }\end{array}$ & $\begin{array}{l}\text { Developmental } \\
\text { Delay }\end{array}$ & $\begin{array}{l}\text { Intellectual } \\
\text { Disability }\end{array}$ & $\begin{array}{l}\text { Neurologic } \\
\text { Findings }\end{array}$ & Epilepsy & Comments \\
\hline 1 & M & NR & Agenesis & $\begin{array}{l}\text { Dysmorphic features } \\
\text { Congenital heart } \\
\text { disease: atrial and } \\
\text { ventricular septal } \\
\text { defect, coarctation } \\
\text { of the aorta, patent } \\
\text { ductus arteriosus } \\
\text { Hypospadias }\end{array}$ & NR & NR & NR & NR & Neonatal death \\
\hline 2 & $\mathrm{~F}$ & NR & Agenesis & $\begin{array}{l}\text { Short rib-polydactyly } \\
\text { syndrome type II } \\
\text { (Majewski) } \\
\text { Cleft palate }\end{array}$ & NR & NR & NR & NR & Neonatal death \\
\hline 3 & M & $7 \mathrm{yr}$ & Agenesis & Dysmorphic features & + & + & - & + & \\
\hline 4 & M & NR & Agenesis & $\begin{array}{l}\text { Dysmorphic features } \\
\text { Congenital heart } \\
\text { disease: double- } \\
\text { outlet right } \\
\text { ventricle, patent } \\
\text { ductus arteriosus } \\
\text { Bilateral inguinal } \\
\text { hernia } \\
\text { (Edwards syndrome) }\end{array}$ & NR & NR & NR & NR & $\begin{array}{l}\text { Trisomy } 18 \\
\text { Neonatal death }\end{array}$ \\
\hline 5 & M & $1 \mathrm{yr}$ & Agenesis & $\begin{array}{l}\text { Dysmorphic features } \\
\text { Blepharophimosis } \\
\text { Corneal opacities of } \\
\text { unknown etiology }\end{array}$ & + & + & $\begin{array}{l}\text { Cerebral palsy: } \\
\text { generalized } \\
\text { hypotonia }\end{array}$ & - & \\
\hline 6 & $\mathrm{~F}$ & NR & Hypoplasia & $\begin{array}{l}\text { Congenital heart } \\
\text { disease: ventricular } \\
\text { septal defect, } \\
\text { coarctation of the } \\
\text { aorta, patent ductus } \\
\text { arteriosus }\end{array}$ & NR & NR & NR & NR & Neonatal death \\
\hline 7 & M & $9 \mathrm{yr}$ & Hypoplasia & Dyscrania & + & + & $\begin{array}{l}\text { Cerebral palsy: } \\
\text { spastic tetraplegia }\end{array}$ & + & \\
\hline 8 & $\mathrm{~F}$ & $1 \mathrm{yr}$ & Hypoplasia & $\begin{array}{l}\text { Dysmorphic features } \\
\text { Congenital heart } \\
\text { disease: atrial septal } \\
\text { defect } \\
\text { Pyelectasis } \\
\text { Umbilical hernia }\end{array}$ & + & + & Hearing loss & + & \\
\hline \multicolumn{10}{|c|}{ * Age at most recent follow-up. } \\
\hline $\begin{array}{l}\text { Abbrevi: } \\
\mathrm{CC}= \\
\mathrm{CNS}= \\
\mathrm{F}= \\
\mathrm{M}= \\
\mathrm{NR}= \\
\mathrm{yr}=\end{array}$ & $\begin{array}{l}\text { ations: } \\
\text { Corpus } \\
\text { Centra } \\
\text { Female } \\
\text { Male } \\
\text { Not rel } \\
\text { Years }\end{array}$ & callost & $\begin{array}{l}\text { m } \\
\text { s system }\end{array}$ & & & & & & \\
\hline
\end{tabular}

retrospective, population-based study. Our results are in good agreement with the findings of a large-scale study in California [14]. Some inaccuracy probably cannot be avoided in a retrospective study. Hence, this survey also contains some limitations. Only live births with callosal anomalies were included in this study, because data on stillbirths or terminated pregnancies were unavailable. No etiology was evident in a number of cases with multiple anomalies. A prospective study including patients receiving an intrauterine diagnosis, and providing more data on patients with callosal abnormalities, will be undertaken in the near future.

S.T. and L.S. were funded by Marie Curie International Reintegration Grant MIRG-CT-2005-030967, within the Sixth European Community Framework Programme. The authors are grateful to Mária Báló, MD, 
Tibor Bodrogi, MD, József Eller, MD, Tímea Fésüs, MD, Judit Gaika, MD, Margit Halenkár, MD, Éva Halics, MD, László Kaizer, MD, István Kovács, MD, Margit Páncsics, MD, Edit Paulik, MD, Judit Sárváry, MD, Irén Simon, MD, András Svékus, MD, Magdolna Sziráczki, MD, Éva Szirovicza, MD, Péter Szücs, MD, Ildikó Tihanyi, MD, and Zsuzsa Vágréti, $\mathrm{MD}$, for providing data used in this study.

\section{References}

[1] Paul LK, Brown WS, Adolphs R, et al. Agenesis of the corpus callosum: Genetic, developmental and functional aspects of connectivity. Nat Rev Neurosci 2007;8:287-99.

[2] Dobyns WB. Absence makes the search grow longer. Am J Hum Genet 1996;58:7-16.

[3] Sowell ER, Mattson SN, Thompson PM, Jernigan TL, Riley EP, Toga AW. Mapping callosal morphology and cognitive correlates: Effects of heavy prenatal alcohol exposure. Neurology 2001;57:235-44.

[4] Nissenkorn A, Michelson M, Ben-Zeev B, Lerman-Sagie T. Inborn errors of metabolism: A cause of abnormal brain development. Neurology 2001;56:1265-72.

[5] Brown GK. Congenital brain malformations in mitochondrial disease. J Inherit Metab Dis 2005;28:393-401.

[6] Schell-Apacik CC, Wagner K, Bihler M, et al. Agenesis and dysgenesis of the corpus callosum: Clinical, genetic and neuroimaging findings in a series of 41 patients. Am J Med Genet [A] 2008;146A:2501-11.

[7] Sztriha L, Frossard P, Hofstra RMW, Verlind E, Nork M. Novel missense mutation in the L1 gene in a child with corpus callosum agenesis, retardation, adducted thumbs, spastic paraparesis, and hydrocephalus. J Child Neurol 2000;15:239-43.

[8] Sztriha L, Vos YJ, Verlind E, Johansen J, Berg B. X-linked hydrocephalus: A novel missense mutation in the LICAM gene. Pediatr Neurol 2002;27:293-6.

[9] Sztriha L, Espinosa-Parrilla Y, Gururaj A, et al. Frameshift mutation of the zinc finger homeo box 1B gene in syndromic corpus callosum agenesis (Mowat-Wilson syndrome). Neuropediatrics 2003;34:322-5.

[10] Sztriha L. Spectrum of corpus callosum agenesis. Pediatr Neuro] 2005;32:94-101.

[11] Garne E, Dolk H, Krägeloh-Mann I, Ravn SH, Cans C; SCPE Collaborative Group. Cerebral palsy and congenital malformations. Eur J Paediatr Neurol 2008;12:82-8.

[12] Jeret JS, Serur D, Wisniewski K, Fisch C. Frequency of agenesis of the corpus callosum in the developmentally disabled population as determined by computerized tomography. Pediatr Neurosci 1985;12:101-3.

[13] Hetts SW, Sherr EH, Chao S, Gobuty S, Barkovich AJ. Anomalies of the corpus callosum: An MR analysis of the phenotypic spectrum of associated malformations. AJR 2006;187:1343-8.

[14] Glass HC, Shaw GM, Ma C, Sherr EH. Agenesis of the corpus callosum in California 1983-2003: A population-based study. Am J Med Genet [A] 2008;146A:2495-500.
[15] van Bon BWM, Koolen DA, Borgatti R, et al. Clinical and molecular characteristics of 1qter microdeletion syndrome: Delineating a critical region for corpus callosum agenesis/hypogenesis. J Med Genet 2008; 45:346-54.

[16] Chadie A, Radi S, Trestard L, et al. Neurodevelopmental outcome in prenatally diagnosed isolated agenesis of the corpus callosum. Acta Paediatr Scand 2008;97:420-4.

[17] Brown WS, Paul LK. Cognitive and psychosocial deficits in agenesis of the corpus callosum with normal intelligence. Cogn Neuropsychiatr 2000;5:135-57.

[18] Paul LK, Lancker-Sidtis DV, Schieffer B, Dietrich R, Brown WS. Communicative deficits in agenesis of the corpus callosum: Nonliteral language and affective prosody. Brain Lang 2003; 85:313-24.

[19] Saint-Amour D, Lepore F, Lassonde M, Guillemot JP. Effective binocular integration at the midline requires the corpus callosum. Neuropsychologia 2004;42:164-74.

[20] Volpe P, Paladini D, Resta M, et al. Characteristics, associations and outcome of partial agenesis of the corpus callosum in the fetus. Ultrasound Obstet Gynecol 2006;27:509-16.

[21] Ghi T, Carletti A, Contro E, et al. Prenatal diagnosis and outcome of partial agenesis and hypoplasia of the corpus callosum. Ultrasound Obstet Gynecol 2010;35:35-41.

[22] Nagamani SCS, Erez A, Eng C, et al. Interstitial deletion of 6q25.2-q25.3: A novel microdeletion syndrome associated with microcephaly, developmental delay, dysmorphic features and hearing loss. Eur J Hum Genet 2009;17:573-81.

[23] Tang PH, Bartha AI, Norton ME, Barkovich AJ, Sherr EH, Glenn OA. Agenesis of the corpus callosum: An MR imaging analysis of associated abnormalities in the fetus. AJNR 2009;30:257-63.

[24] Garcia-Filion P, Epport K, Nelson M, et al. Neuroradiographic, endocrinologic, and ophthalmic correlates of adverse developmental outcomes in children with optic nerve hypoplasia: A prospective study. Pediatrics 2008;121:e653-9.

[25] Barkovich AJ. Congenital malformations of the brain and skull. In: Barkovich AJ, editor. Pediatric neuroimaging. 3rd ed. Philadelphia: Lippincott Williams \& Wilkins, 2000:251-381.

[26] Bodensteiner JB, Schaefer GB. Wide cavum septum pellucidum: A marker of disturbed brain development. Pediatr Neurol 1990;6: 391-4.

[27] Kuchelmeister K, Garcia H. Schwere zerebrale Missbildungen bei atypischem Short-Rib-Polydactyly Syndrome (SRP-S). Zentralbl Allg Pathol 1988;134:561-6.

[28] Prudlo J, Stoltenburg-Didinger G, Jimenez E, CervósNavarro J. Central nervous system alterations in a case of short-rib polydactyly syndrome, Majewski type. Dev Med Child Neurol 1993; 35:158-76.

[29] Sherr EH, Owen R, Albertson DG, et al. Genomic microarray analysis identifies candidate loci in patients with corpus callosum anomalies. Neurology 2005;65:1496-8. 